\title{
Morphological and Physico-Chemical Characteristics and Classification of Vertisol Developed on Deltaic Plain
}

\author{
Orhan Dengiz*, Mustafa Sağlam, F. Esra Sarioğlu, Fikret Saygin, Çağla Atasoy \\ Department of Soil Science and Plant Nutrition, Faculty of Agriculture, Ondokuz Mayıs University, Samsun, Turkey. \\ Email: *odengiz@omu.edu.tr
}

Received January $27^{\text {th }}, 2012$; revised February $24^{\text {th }}, 2012$; accepted March $8^{\text {th }}, 2012$

\begin{abstract}
The name of Vertisol is derived from Latin "vertere" meaning to invert. This case restricts development of soil horizons in profile. These soils have the capacity to swell and shrink, inducing cracks in the upper parts of the soil and distinctive soil structure throughout the soil. The formation of these specific features are caused by a heavy texture, a dominance of swelling clay in the fine fraction and marked changes in moisture content. The swell-shrink behavior is attributed to the wetting and drying of the soil mass. In this study, morphology, physico-chemical characteristics and classification of vertisols that were formed on alluvial delta plains, were investigated. Those soils formed on the Bafra Plain found in the Kızllırmak Delta and located in the central Black Sea region of Turkey. All studied Vertisols are characterised by a dark colour in surface soil, a heavy clayey texture, hardpan formation under top soil (high bulk density a high compaction) and very high COLE values. In addition, they have deep wide-opened desiccation cracks at the surface, slickensides at the middle part of the profiles and a poor differentiation of their horizons. Physico-chemically, the studied soils are slightly basic to very basic, non-saline and poor in organic matter, which is slightly higher in the surface horizon. In addition, cation exchange capacity, sum of exchangeable bases and base saturation of soils are very high. On the basis of morphological and physicochemical analysis, soil profiles were classified as Sodic Haplustert, Typic Calciaquert, Sodic Calciustert according to Soil Taxonomy (Soil Survey Staff, 1975 and 1999) and as Sodic Vertisol and Calcic Vertisol according to FAO/ISRIC (2006) classification systems.
\end{abstract}

Keywords: Vertisol; Soil Morphology; Soil Classification; Bafra Delta Plain

\section{Introduction}

The materials that form vertisols can be either allochtonous or autochtonous in origin [1]. The former are geographically more extensive and generally occur in the lower parts of the landscape. Vertisols are known to develop on a wide variety of parent materials such as basalts in Australia [2], calcareous rocks in the West Indies [1], gneisses and sandstones in India [3], deltaic deposits in the United States of America [4], lacustrine deposits in Trinidad [5], glacio-lacustrine in Saskatchewan [6], marine deposits in Guyana [7], and marls [8]. It is reported that in all cases (except for the vertisols developed on lacustrine deposits), the materials were recently deposited and that soil formation was still at its early stages [9]. In the case of vertisols developed from lacustrine deposits in Trinidad, it is believed that extensive weathering and clay-mineral synthesis had occurred prior to deposition [10].

The name of vertisol is derived from Latin "vertere"

${ }^{*}$ Corresponding author. meaning to invert. This case restricts development of soil horizons in profile [9]. These soils have the capacity to swell and shrink, inducing cracks in the upper parts of the soil and distinctive soil structure throughout the soil [11]. The formation of these specific features are caused by a heavy texture, a dominance of swelling clay in the fine fraction and marked changes in moisture content [12]. The swell-shrink behaviour is attributed to the wetting and drying of the soil mass. Vertisols exhibit cracks a depth of $50 \mathrm{~cm}$ down that are at least $1 \mathrm{~cm}$ wide and extend upward to the surface or the base of the plough layer or surface crust. These soils exhibit minimal horizon differentiation as a result of pedoturbation. They are also very plastic and sticky when wet [13]. Vertisols are described by Glossary of Soil Science Terms [14] as "mineral soils that have $30 \%$ or more clay, deep wide cracks when dry and either gilgai microrelief, intersecting slickenside or wedge-shaped structural aggregates tiled at an angle from the horizon. It was added as an order in US system of soil taxonomy.

Depressions and level to undulating areas, mainly in 
tropical, semi arid to sub humid and Mediterranean climates with and alternation of district wet and dry seasons. An estimated 150 million hectares is potential crop land [15]. According to a map called the Turkey Soil Zones Map at the scale of 1:2,000,000 prepared from the results of the Turkey Development Soil Maps Survey at a scale of 1:100,000, vertisols comprise 598,693 hectares or 0.86 percent of the land area of Turkey $[16,17]$.

Vertisols are important agricultural soils in left side of Bafra Delta Plain. Soils are mostly used for rice cultivation. The main aims of this research were to determine the morphological and some physico-chemical characteristics of these soils and to classify the soils according to the USDA Soil Taxonomy and FAO/ISRIC soil classification systems.

\section{Material and Methods}

\subsection{Description of the Study Area}

This study was carried out in the left side of Bafra Plains found in the Kızılırmak delta located in the central Black Sea region of Turkey (Figure 1). The Bafra Delta Plain is far $30 \mathrm{~km}$ from north of the Samsun province. The current climate in the region is semi-humid. The summers are warmer than winters (the average temperature in July is 22.2 and in January is $6.9^{\circ} \mathrm{C}$ ). The mean annual temperature, rainfall and evaporation are $13.6^{\circ} \mathrm{C}, 764.3 \mathrm{~mm}$ and $726.7 \mathrm{~mm}$ respectively. According to [18], soil temperature regime is mesic and moisture regime is ustic in the study area. The mean annual temperature, rainfall and evaporation are $13.6^{\circ} \mathrm{C}, 764.3 \mathrm{~mm}$ and $726.7 \mathrm{~mm}$ respectively in Bafra plain that area is mainly flat and slightly

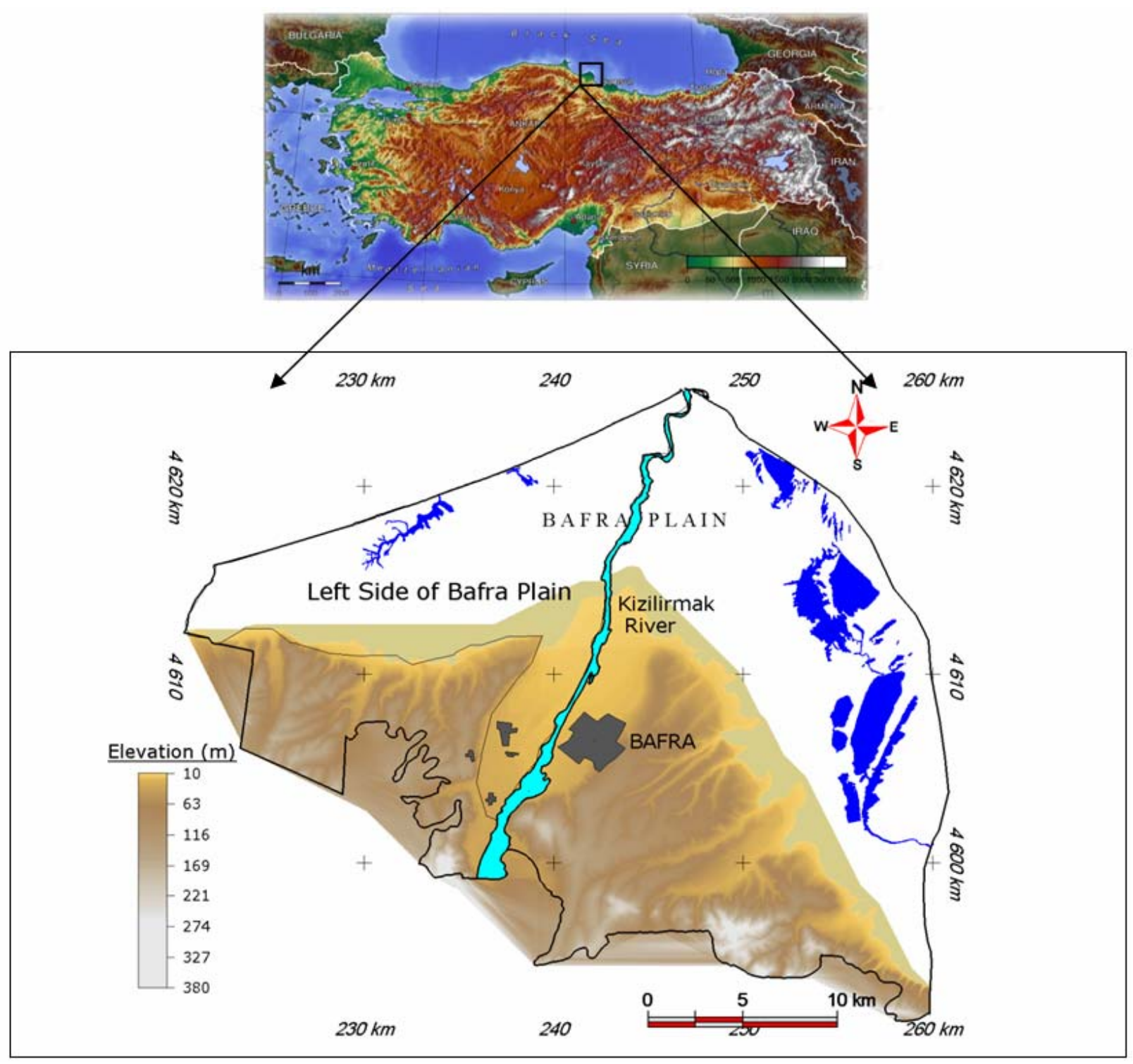

Figure 1. Location map of the study area. 
sloped $(0 \%-2.0 \%)$. The study area has been under intensive agricultural activities. Rice, wheat, maize, pepper, watermelon, cucumber and tomato with sprinkler and furrow irrigations in the summer, and cabbage and leek in the winter have been produced in the study area.

\subsection{Physical and Chemical Analysis}

Four vertisol profiles formed on deltaic deposits were selected for this study in left side of Bafra delta plains. Morphological properties of these four soil profiles in the field were identified and sampled by genetic horizons. Nineteen soil samples were taken to investigate for their physical and chemical properties at the laboratory. Disturbed soil samples were dried under atmospheric condition and passed through a $2 \mathrm{~mm}$ sieve to prepare for laboratory analysis. In soil samples, particle size distribution was determined by the hydrometer method [19]. Dry bulk density was determined by the core method [20]. Soil reaction (pH), electrical conductivity (EC) and $\mathrm{CaCO}_{3}$ content were determined by standard procedure [21]. Ex- changeable cations and cation exchange capacities (CEC) were measured using a $1 \mathrm{~N} \mathrm{NH}_{4} \mathrm{OAc}(\mathrm{pH} 7)$ extraction method [22]. Organic matter content was determined using the Walkley-Black wet digestion method [23]. Coefficient of linear extensibility (COLE) was determined according to [18]. In addition, these four soil profiles were classified according to [18-24].

\section{Results and Discussions}

\subsection{Soil Morphology and Classification}

Two main types of vertisols can be distinguished: Lithomorphic vertisols and topomorphic vertisols [24,25]. Lithomorphic vertisols are formed on various parent rocks whose weathering generates base-rich environments favourable for smectite synthesis, while topomorphic vertisols are formed mainly in favour of low landscape positions which favour the accumulation of bases. In this study, morphological characteristics of selected four soil profiles formed on alluvial delta plains are presented in Table $\mathbf{1 .}$

Table 1. Selected morphological characteristics of pedons.

\begin{tabular}{|c|c|c|c|c|c|c|c|}
\hline \multirow{2}{*}{ Horizon } & \multirow{2}{*}{$\begin{array}{l}\text { Depth } \\
\text { (cm) }\end{array}$} & \multirow{2}{*}{ Boundary } & \multicolumn{2}{|l|}{ Colors } & \multirow{2}{*}{-Structure } & \multirow{2}{*}{ Consistence } & \multirow{2}{*}{ Special features } \\
\hline & & & Dry & Moist & & & \\
\hline \multicolumn{8}{|c|}{ Pedon I (Sodic Haplustert/Sodic Vertisol) } \\
\hline Ap & $0-18$ & as & 10YR3/2 & 10YR3/3 & $3 \mathrm{mgr}$ & sh fi st pt & cracks \\
\hline Bss1 & $18-45$ & $\mathrm{CW}$ & $10 \mathrm{YR} 4 / 3$ & $10 \mathrm{YR} 4 / 3$ & 3mabk & h fi st pt & cracks, slickenside \\
\hline Bss2 & $45-70$ & $\mathrm{dw}$ & $2.5 \mathrm{YR} 6 / 2$ & $2.5 \mathrm{YR} 5 / 2$ & $3 \mathrm{mpr}$ & h fi st pt & cracks, slickenside \\
\hline Bss3 & $70-116$ & $\mathrm{dw}$ & $2.5 \mathrm{YR} 5 / 3$ & $2.5 \mathrm{YR} 5 / 3$ & $3 \mathrm{cpr}$ & h fi st pt & cracks, slickenside \\
\hline $\mathrm{C}$ & $116+$ & - & $10 \mathrm{YR} 5 / 3$ & $10 Y R 5 / 4$ & $\mathrm{~m}$ & h fi st pt & - \\
\hline \multicolumn{8}{|c|}{ Pedon II (Typic Calciaquert/Calcic Vertisol) } \\
\hline Ap & $0-25$ & aw & $2.5 \mathrm{YR} 4 / 3$ & $2.5 \mathrm{YR} 4 / 4$ & $3 m g r$ & h fi st pt & cracks \\
\hline Bss1 & $25-70$ & $\mathrm{CW}$ & $5 Y 5 / 3$ & $5 Y 5 / 2$ & $3 \mathrm{mpr}$ & h fi st pt & cracks \\
\hline Bss2 & $70-116$ & CS & $5 Y 6 / 1$ & $5 Y 6 / 2$ & $3 \mathrm{mpr}$ & h fi st pt & slickenside \\
\hline \multicolumn{8}{|c|}{ Pedon III (Sodic Haplustert/Sodic Vertisol) } \\
\hline Ap & $0-15$ & as & $2.5 \mathrm{YR} 4 / 3$ & $2.5 Y R 4 / 3$ & 3mgr & sh fi st pt & cracks \\
\hline Ad & $15-44$ & gw & $2.5 \mathrm{YR} 5 / 3$ & $2.5 Y R 4 / 4$ & 3msbk & h fi st pt & densitic layer \\
\hline Bssg1 & $44-73$ & gw & 10GY6/1 & $10 \mathrm{GY} 5 / 1$ & $3 \mathrm{mpr}$ & h fi st pt & slickenside, redoximorphic feature \\
\hline Bssg2 & $73-108$ & $\mathrm{dw}$ & $10 \mathrm{GY} 6 / 1$ & $10 \mathrm{GY} 5 / 1$ & $2 \mathrm{mpr}$ & h fi st pt & slickenside, redoximorphic feature \\
\hline $\mathrm{Cg}$ & $108+$ & - & $2.5 Y R 6 / 3$ & $2.5 Y R 6 / 3$ & $\mathrm{~m}$ & sh fi ss pt & redoximorphic feature \\
\hline \multicolumn{8}{|c|}{ Pedon IV (Sodic Calciustert/Sodic Vertisol) } \\
\hline Ap & $0-18$ & as & $10 \mathrm{YR} 4 / 2$ & $10 \mathrm{YR} 3 / 2$ & 3cgr & sh fi st pt & cracks \\
\hline Ad & $18-50$ & aw & $10 Y R 4 / 3$ & $10 Y R 3 / 4$ & 3msbk & sh fi st pt & densitic layer \\
\hline Bss & $50-82$ & $\mathrm{CW}$ & $2.5 \mathrm{YR} 6 / 3$ & $2.5 Y R 6 / 3$ & $3 \mathrm{mpr}$ & sh fi st pt & slickenside \\
\hline Bssk & $82-125$ & $\mathrm{CW}$ & $2.5 Y R 7 / 3$ & $2.5 Y R 6 / 3$ & $3 \mathrm{mpr}$ & si fi st pt & $\begin{array}{l}\text { slickenside, carbonate mycelium } \\
\text { and nodules }\end{array}$ \\
\hline
\end{tabular}

Abbreviations: Boundary: a = abrupt; c = clear; $\mathrm{g}$ = gradual; $\mathrm{d}$ = diffuse; $\mathrm{s}=$ smooth; $\mathrm{w}$ = wavy; $\mathrm{i}=$ irregular Structure: 1 = weak; 2 = moderate; 3 = strong; sg = single grain; $\mathrm{m}$ = massive; $\mathrm{vf}=$ very fine; $\mathrm{f}=$ fine; $\mathrm{m}=$ medium; $\mathrm{c}=$ coarse; gr = granular; $\mathrm{pr}=$ prismatic; abk = angular blocky; sbk = subangular blocky. Consistance: (Dry) lo = loose; so = soft; sh = slightly hard; $\mathrm{h}=$ hard; (Moist) lo = loose; vfr = very friable; fr = friable; fi = firm; $($ Wet) so = nonsticky; ss = slightly sticky; st = sticky; po = nonplastic; ps = slightly plastic; $\mathrm{pt}=$ plastic. 
$[11,26,27]$ stated that many vertisols have deep and dark topsoil. In addition, [28] reported the dark colour (low chroma) could be related to the strong impregnation of profile by organic matter during pedogenesis or to prolong waterlogging. In this research, colour of the all profiles in hue changed 10YR and 2.5Y, value was 3 - 4 (dry and moisture conditions) in surface soils. Thus, the finding was showed coherent with these researchers. On the other hand, colour changed due to redoximorphic feature (10GY 6/1) in subsurface horizon in Profile III and carbonate accumulation (high value-2.5YR7/3) in Ck and Bssk horizons of PII and PIV. Besides, carbonate nodules and mycelium were also recognised in these pedons within $120 \mathrm{~cm}$ depth due to calcification process.

Extensive swelling and shrinking upon wetting and drying is the major characteristics of these soils. This results to pedoturbation or mixing of the soils and minimal horizonation [9]. Shrinkage causes the formation of wide deep cracks and washing of surface materials into these cracks. Vertisols may exhibit open cracks, which are up to $50 \mathrm{~cm}$ deep and at least $1 \mathrm{~cm}$ wide and extend upward to the surface or the base of the plow layer or surface crust [13]. Moreover, cracks are a unique feature in soils with strong shrink-swell potential and are used as one of the criteria in defining vertisols and vertic intergrades in soil taxonomy [18]. Cracking takes place as a result of seasonal fluctuation. The moisture regime influences the duration and intensity of cracking. The degree and frequency of changes in moisture content of the soil are perhaps the most important parameters that control cracking intensity [6]. Cyclic cracking and swelling contribute to the formation of slickensides. Most of the subsurface horizons (except for $\mathrm{C}$ horizons) of profiles were characterised by numerous smooth and shiny surfaces called slickensides that separated different blocks and prismatic; their diameters varied between 5 and $15 \mathrm{~cm}$. While Ap horizons of profiles have strong, medium and coarse granular structures, due to high clay content blocky and prismatic structures were determined in $100 \mathrm{~cm}$ of profiles. Consistencies of all B horizon of profiles were very hard when dry and plastic when wet conditions.

Due to the fact that main soil formation process and other features such as slickenside, cracking, carbonate accumulation and redoximorphic symptoms, four soil profiles were classified as Sodic Haplustert, Typic Calciaquert, Sodic Calciustert by taking into consideration of Soil Taxonomy [18]. In addition, these soils were classified as Sodic Vertisol and Calcic Vertisol according to FAO/ISRIC [24].

\subsection{Physico-Chemical Characteristics}

\subsubsection{Chemical Properties}

Vertisols are generally found on sedimentary plains as the result of thousands of years eroding the clay content out of the surrounding hills. They can also be found on level land and in depressions. [29] also reported that vertisols are typically developed on alluvial material in flat inland areas. The pedons selected for the present study, it was found significantly vation in $\mathrm{pH}$ values among all the soil layers. The $\mathrm{pH}$ values varied from 7.84 to 9.39 . The increase in $\mathrm{pH}$ with depth of pedons is a characteristic feature of all pedons and could imply the proximity of the horizons to the alluvial parent material that is rich in alkaline earth cations ( $\mathrm{Ca}$ and $\mathrm{Mg}$ ) and water table fluctuation due to sea effect that includes high sodium ion concentration. In parallel, increasing of sodium concentration with depth caused increasing of ESP values in all pedons. [30] reported that high ESP values in vertisols cause dispersion of fine particles, leading to blockade of pore spaces. This ultimately renders the soils non-porous as reflected by low permeability. Poor drainage conditions lower the rate of organic matter decomposition. The organic matter values varied from $3.2 \%$ to $4.8 \%$ in surface horizons whereas, these ratios decreased with depth and varied from $0.5 \%$ to $2.5 \%$. The higher organic matter at the surface could be linked to the continuous addition of crop residues on the surface of cropped fields in the area. The cation exchange capacity for all the studied soils ranged between 32.6 and $80.7 \mathrm{cmol} \cdot \mathrm{kg}^{-1}$ of soils (Table 2). It increased regularly with profile depth. Calcium and magnesium were the dominant exchangeable cations, with contents ranging between 25.6 and $73.5 \mathrm{cmol} \cdot \mathrm{kg}^{-1}$ of soils. It was followed by sodium (3.0 to $12.2 \mathrm{cmol} \cdot \mathrm{kg}^{-1}$ ), while potassium showed more modest values (0.6 to 1.0 $\mathrm{cmol} \cdot \mathrm{kg}^{-1}$ ). The $\mathrm{CaCO}_{3}$ content of the soils increased with depth and values varied from $1.4 \%$ to $34.7 \%$. The highest values were observed at the subsurface horizons in Profile II and Profile IV due to calcium carbonate leaching and accumulation process. [31] reported that pedogenic carbonates accumulation in the Texas Gulf Coast Prairie Vertisols form by leaching of detrital carbonate in the fine earth fraction of the sediments to just below the effective meteoric infiltration.

\subsubsection{Physical Properties}

The soils selected for the present study belong to vertisols and their intergrades. Logically, the sand, silt and clay content should be within the range to qualify them as Vertisols [18]. The contents of sand, silt and clay vary as shown in Table 3. The clay content of all studied pedons varies from $52.2 \%$ to $85.7 \%$ except for $C$ horizons of pedons while, sand content changes between $5.3 \%$ $17.6 \%$ in pedogenetic horizons. While the clay contents were the highest in Pedon IV and ranged between 80.1\% and $85.7 \%$ within $80 \mathrm{~cm}$ depth, the highest sand content (20.0\%) was observed in Pedon II. The representation of various grain size fractions on [32] Jamagne's textural diagram showed that the all soils layers of pedons had a heavy clayey texture (Figure 2). 
Table 2. Some chemical properties of pedons.

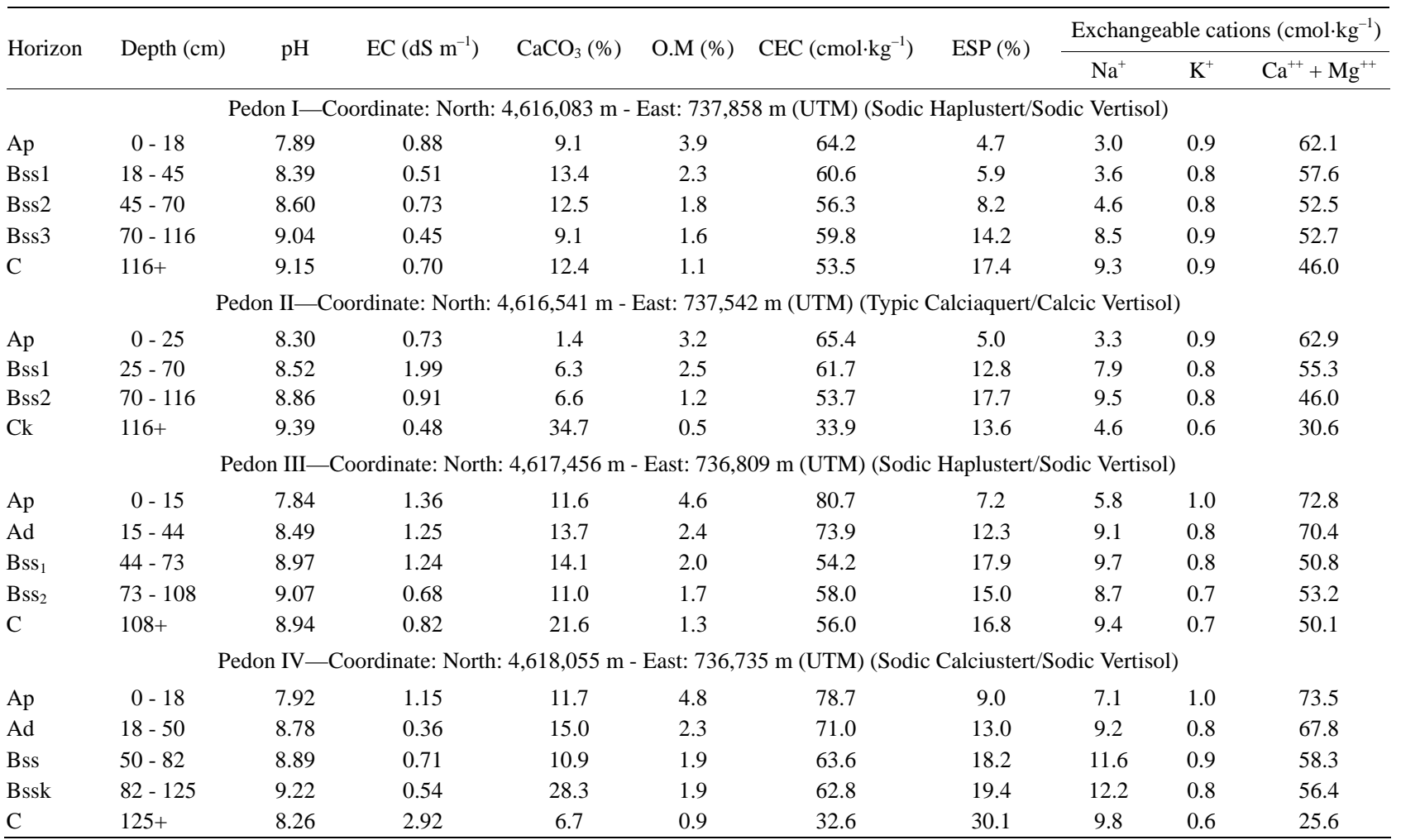

EC: Electrical conductivity; CEC: Cation exchange capacity; O.M: Organic matter; ESP: Exchangeable sodium percentage.

Table 3. Some physical properties of pedons.

\begin{tabular}{|c|c|c|c|c|c|c|c|}
\hline \multirow{2}{*}{ Horizon } & \multirow{2}{*}{ Depth (cm) } & \multirow{2}{*}{ COLE } & \multicolumn{4}{|c|}{ Particle size distribution (\%) } & \multirow{2}{*}{$\begin{array}{c}\mathrm{BD} \\
\left(\mathrm{gr}^{\circ} \mathrm{cm}^{-3}\right)\end{array}$} \\
\hline & & & Clay & Silt & Sand & Class & \\
\hline \multicolumn{8}{|c|}{ Pedon I (Sodic Haplustert/Sodic Vertisol) } \\
\hline Ap & $0-18$ & 0.221 & 68.1 & 24.2 & 7.8 & $\mathrm{C}$ & 1.15 \\
\hline Bss1 & $18-45$ & 0.274 & 66.0 & 23.4 & 10.6 & $\mathrm{C}$ & 1.21 \\
\hline Bss2 & $45-70$ & 0.264 & 65.1 & 21.8 & 13.0 & $\mathrm{C}$ & 1.23 \\
\hline C & $116+$ & 0.225 & 72.9 & 13.7 & 13.5 & $\mathrm{C}$ & 1.34 \\
\hline \multicolumn{8}{|c|}{ Pedon II (Typic Calciaquert/Calcic Vertisol) } \\
\hline Ap & $0-25$ & 0.211 & 68.1 & 17.4 & 14.5 & $\mathrm{C}$ & 1.24 \\
\hline Bss1 & $25-70$ & 0.281 & 72.1 & 15.7 & 12.2 & $\mathrm{C}$ & 1.22 \\
\hline Bss2 & $70-116$ & 0.191 & 61.5 & 17.5 & 21.0 & $\mathrm{C}$ & 1.27 \\
\hline Ck & $116+$ & 0.025 & 28.9 & 35.3 & 35.8 & $\mathrm{~L}$ & 1.35 \\
\hline Ap & $0-15$ & 0.280 & 79.7 & 13.3 & 7.0 & $\mathrm{C}$ & 1.23 \\
\hline Ad & $15-44$ & 0198 & 80.4 & 9.1 & 10.5 & $\mathrm{C}$ & 1.48 \\
\hline Bss1 & $44-73$ & 0.190 & 55.1 & 29.4 & 15.4 & $\mathrm{C}$ & 1.27 \\
\hline Bss2 & $73-108$ & 0.191 & 52.2 & 34.9 & 13.0 & $\mathrm{C}$ & 1.30 \\
\hline $\mathrm{C}$ & $108+$ & 0.111 & 40.5 & 10.7 & 48.8 & $\mathrm{C}$ & 1.50 \\
\hline \multicolumn{8}{|c|}{ Pedon IV (Sodic Calciustert/Sodic Vertisol) } \\
\hline Ap & $0-18$ & 0.269 & 80.5 & 11.0 & 8.5 & $\mathrm{C}$ & 1.20 \\
\hline Ad & $18-50$ & 0.219 & 85.7 & 9.0 & 5.3 & $\mathrm{C}$ & 1.57 \\
\hline Bss & $50-82$ & 0.231 & 80.1 & 2.3 & 17.6 & $\mathrm{C}$ & 1.31 \\
\hline Bssk & $82-125$ & 0.174 & 62.5 & 25.9 & 11.6 & $\mathrm{C}$ & 1.35 \\
\hline $\mathrm{C}$ & $125+$ & 0.021 & 23.5 & 53.6 & 22.9 & SiL & 1.55 \\
\hline
\end{tabular}

COLE: Coefficient of linear extensibility; BD: Dry bulk density; C: Clay, SiL: Silty loam; L: Loam 


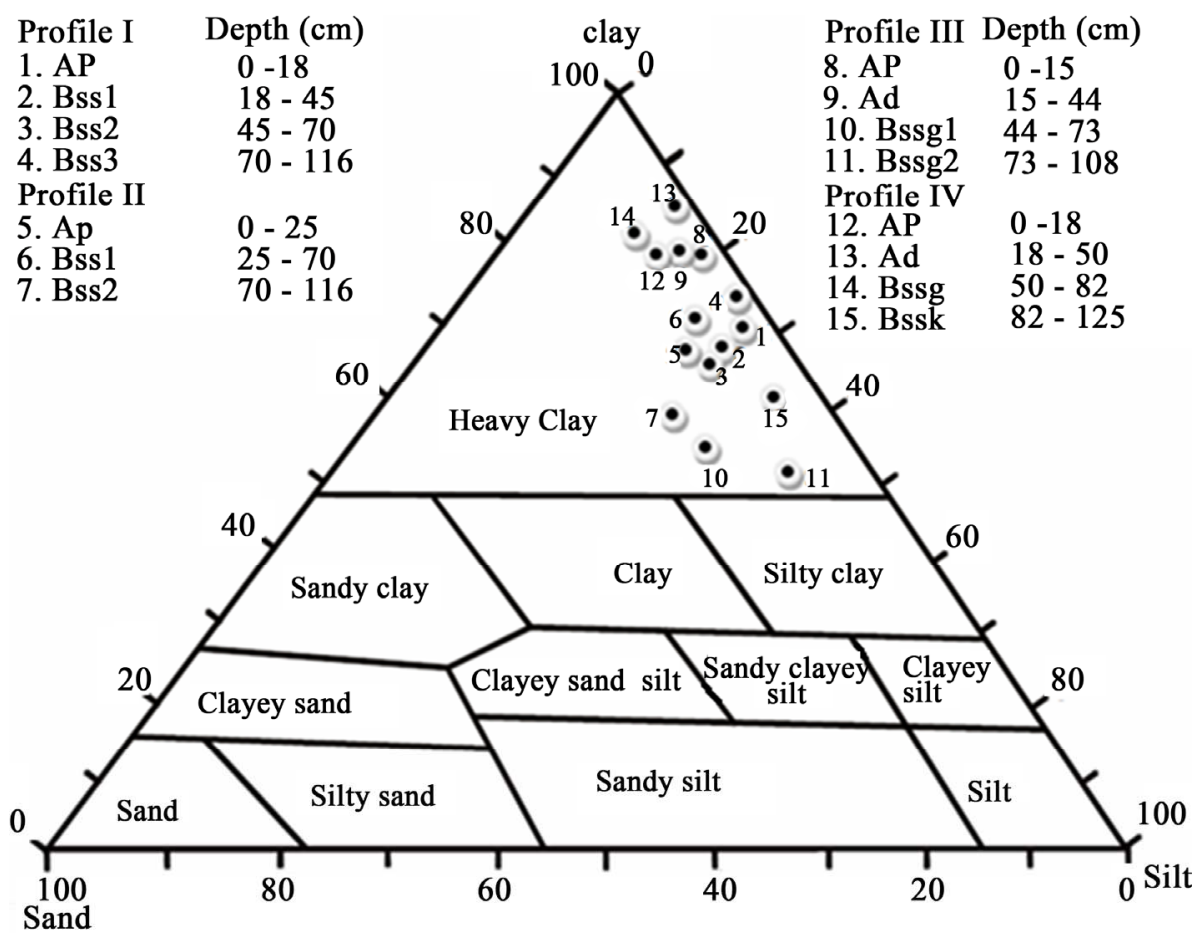

Figure 2. Soil textural classes with reference to Jamagne's triangle (1967).

Bulk density (BD) indicates the weight of all the organic and inorganic materials of a given volume of soil. Higher organic matter lowers BD. High clay content and introduction of farm machinery causes compaction of subsurface layer, which increases the BD. Bulk density also varies with the content of coarser fragments in soils. There is a growing acceptance of the view that $\mathrm{BD}$ changes due to change in land use pattern [33]. A study was conducted with soil profiles from arable area used for field crop (rice) and vegetables for 30 - 40 years. The highest BDs were determined in parent materials of all pedons including high sand content. On the other hand, BD of pedogenetic horizons ranges between 1.15 and $1.35 \mathrm{~g} \cdot \mathrm{cm}^{-3}$ except for Ad horizons of Pedon III and IV that soils have particularly used for rice cultivation. Due to heavy tillage system and field traffic on these soils leading to hard pan formation, BD increased $1.57 \mathrm{~g} \cdot \mathrm{cm}^{-3}$. Similar results were reported by [34] that over the years, continuous tillage practices resulted bulk density increased from $1.22 \mathrm{~g} \cdot \mathrm{cm}^{-3}$ to $1.38 \mathrm{~g} \cdot \mathrm{cm}^{-3}$ in a tropical forest ecosystem of Bangladesh. In addition, due to compression caused by overburden weight, the BD values usually increase with soil depth in all pedons. It has been reported that vertisols may have BD values as high as $2.1 \mathrm{~g} \cdot \mathrm{cm}^{-3}$ [35]. It has been also shown that at the swelling limit, the gravimetric water content decreases and BD values increase with depth [36].

Coefficient of linear extensibility (COLE) helps to predict the potential of a soil to shrink and swell. The LE of a soil layer is the product of the thickness in centimetres, multiplied by the COLE of the layer in question. The
COLE of a soil is the sum of these products for all soil horizons [18]. According to soil taxonomy, a soil should be qualified for vertic subgroups if the COLE value is more or equal to 6 between the mineral soil surface and either a depth of $100 \mathrm{~cm}$ or a lithic contact, whichever is shallower. In case of vertisols slickensides, cracks and higher COLE values are mutually inclusive. Since higher COLE values indicate the presence of more shrink-swell minerals, namely smectite, a positive correlation between COLE and smectite content can exist [37]. According to COLE classification given in Table 4, it was also found that high COLE values should have a positive relation with vertic characteristic properties of shrink-swell soils and cracking and vary from 0.174 to 0.281 in pedogenetic horizons of all pedons in Table 3.

Vertisols are important agricultural soils in left side of Bafra Delta Plain. However, vertisols are difficult to work, they are of very hard consistence when dry and very plastic and sticky when wet. Therefore, the workability of the soil is often limited to very short periods of medium (optimal) water status. Vertisols are imperfectly to poorly drained, leaching of soluble weathering products is limited, the contents of available sodium, calcium and magnesium are high and the $\mathrm{pH}$ is usually above 7.5. Once they have reached their field capacity, practically no water movement occurs, this is due to the very low hydraulic conductivity of a vertisol. In addition, flooding leading to crop damage can be a major problem in areas with higher rainfall. 
Table 4. Coefficient of linear extensibility (COLE) classification.

\begin{tabular}{ll}
\hline Class & COLE \\
\hline Low & $<0.03$ \\
Moderate & $0.03-0.06$ \\
High & $0.06-0.09$ \\
Very high & $>0.09$ \\
\hline
\end{tabular}

\section{Conclusion}

In this study, it was aimed at investigating the morpological and analytical characteristics of vertisols formed on fluvial land in Bafra Deltaic Plain, in order to highlight their particularities as well as to envisage their practical uses and management. From the morphological and physical point of view, the vertisols of the Bafra Deltaic Plain region are characterised by a dark colour, a heavy clayey texture, hardpan formation under top soil (high bulk density a high compaction) and very high COLE value, deep wide-opened desiccation cracks at the surface, slickensides at the middle part of the profiles and a poor differentiation of their horizons. Physico-chemically, the studied soils are slightly basic to very basic, non-saline and poor in organic matter, which is slightly higher in the surface horizon. Cation exchange capacity, sum of exchangeable bases and base saturation are very high. Overall, considering their characteristics in majority similar to those of a majority of world deltaic vertisols, those soils are still unused or are used only for extensive grazing, wood chopping, charcoal burning and the like [24]. In agriculture, optimum yields could be attained if appropriate management techniques are set up for a more efficient exploitation, protection and conservation of these soils. The comparatively good chemical fertility and their occurrence on extensive level plains where reclamation and mechanical cultivation can be envisaged are assets of vertisols. Their physical soil characteristics and, notably, their difficult water management cause problems. The physical properties and the soil moisture regime of vertisols represent serious management constraints. The heavy soil texture and domination of expanding clay minerals result in a narrow soil moisture range between moisture stress and water excess. Tillage is hindered by stickiness when the soil is wet and hardness when it is dry. The susceptibility of vertisols to waterlogging may be the single most important factor that reduces the actual growing period. Especially due to those properties, these vertisol soils have been generally used for rice cultivation in the study area. On the other hand, this case is not suitable other plants. Particularly, due to their very high of COLE values, namely, very high shrink-swell potential plant roots can be damaged from this soil activity. Zero till is commonly advocated as a preferred cropping system to conventional, multicultivation practices. Zero till is particularly attractive on clay soils to minimize compaction and induce natural structure formation [17]. In particular, the soil structure of vertisols has strong potential to attain optimal conditions for plant growth through activation of their inbuilt resiliency via shrink-swell cycles [38,39]. It is accepted that the major purposes of tillage are to reduce bulk density and soil strength and to control pests and diseases $[40,41]$. However, soil cultivation affects soil quality in various ways. With high clay content, cultivation may lead to the formation of a hard pan below the plough layer that restricts root penetration and downward movement of water [42]. Therefore, many researchers strongly recommend that close attention should be taken into account for the soil cultivation, irrigation system and time depending on the these soil types.

\section{REFERENCES}

[1] N. Ahmad and R. L. Jones, "Genesis, Chemical Properties and Mineralogy of Limestone Derived Soils, Barbados, West Indies,” Journal of Tropical Agriculture, Vol. 46, 1969, pp. 1-15.

[2] J. S. Hosking, "A Comparative Study of the Black Earths of Australia and the Regur of India," Transactions of the Royal Society of South Australia, Vol. 59, 1935, pp. 168-200.

[3] D. V. Bal, "Some Aspects of the Black Cotton Soils of the Central Provinces," Transactions of the 3rd International Congress of Soil Science, Vol. 3, 1935, pp. 154-158.

[4] G. W. Kunze, H. Oakes and M. E. Bloodworth, "Grumusols of the Coastal Prairie of Texas," Soil Science Society of America Journal, Vol. 27, No. 4, 1963, pp. 412-421. doi:10.2136/sssaj1963.03615995002700040019x

[5] C. B. Brown and G. S. Bally, "Land Capability Survey of Trinidad and Tobago," Government Printer, Port of Spain, 1968.

[6] A. R. Mermut, D. F. Acton and C. Tarnocai, "A Review of Recent Research on Swelling Clay Soils in Canada,” In: J. M. Kimble, Ed., Proceeding of the Sixth International Soil Correlation Meeting, Characterization Utilization of Cold Aridisols and Vertisols, Soil Survey Division USDASCS, Washington DC, 1990, p. 253.

[7] Food and Agriculture Organization of the United Nations, "Report on the Soil Survey Project of British Guiana," FAO, Rome, 1966.

[8] P. Duchafour, "Pedologie 1 Pedogenese et Classification," Masson, Paris, 1977.

[9] N. Ahmad, "Vertisols,” In: L. P. Wilding, N. E. Smeck and G. F. Hall, Eds., Pedogenesis and Soil Taxonomy. II. The Soil Orders. Developments in Soil Science IIB, Elsevier. Amsterdam, 1983, pp. 91-123.

[10] G. Rodrigues and F. Hardy, "Soil Genesis from a Sedimentary Clay in Trinidad," Soil Science, Vol. 64, No. 2, 1947, pp. 127-142. doi:10.1097/00010694-194708000-00005

[11] N. Ahmad and A. Marmut, "Vertisols and Technologies for Their Management,” Elsevier, Amsterdam, 1996. 
[12] G. D. Hubble, “The Cracking Clay Soils, Definition, Distribution, Nature, Genesis and Use,” In: J. W. McGarity, E. H. Hoult and H. B. So, Eds., The Properties and Utilization of Cracking Clay Soils, Review in Rural Science, University of New England Armidale, New South Wales, 1984, pp. 3-13.

[13] Soil Survey Staff, "Soil Taxonomy. A Basic System of Soil Classification for Making and Interpreting Soil Surveys," U.S. Department of Agriculture, Washington DC, 1975.

[14] Soil Science Society of America, "Glossary of Soil Science Terms,” SSSA, Wisconsin DC, 1997.

[15] P. M. Driessen and R. Dudal, "Geography Formation, Properties and Use of the Major Soils of the World," The Netherlands and Catholic University, Luven, 1989.

[16] Anonymous, "According to FAO-UNESCO and New Soil Taxonomy the GDRS,” General Directorate of Rural Services, Ankara, 1999.

[17] G. Özsoy and E. Aksoy, "Characterization, Classification and Agricultural Usage of Vertisols Developed on Neogen Aged Calcareous Marl Parent Materials,” Journal of Biological \& Environmental Sciences, Vol. 1, No. 1, 2007, pp. 5-10.

[18] Soil Survey Staff, "Soil Taxonomy USDA Agricultural Handbook," Natural Resources Conservation Service, Washington DC, 1999.

[19] G. J. Bouyoucos, "A Recalibration of the Hydrometer Method for Making Mechanical Analysis of Soils," Agronomy Journal, Vol. 43, 1951, pp. 435-438. doi:10.2134/agronj1951.00021962004300090005x

[20] G. R. Blacke and K. H. Hartge, “Bulk Density,” In: A. Klute, Ed., Methods of Soil Analysis. Part 1. Physical and Mineralogical Methods, American Society of Agronomy- Soil Science Society of America, Madison, 1986, pp. 363-382.

[21] Soil Survey Staff, "Soil Survey Manual. USDA, Handbook," Natural Resources Conservation Service, Washington DC, 1993.

[22] Soil Survey Staff, "Procedures for Collecting Soil Samples and Methods of Analysis for Soil Survey," U.S. Government Print Office, Washington DC, 1992.

[23] D. W. Nelson, L. E. Sommers, "Total Carbon, Organic Carbon and Organic Matter,” In: L. A. Page, R. H. Miller and D R. Keeney, Eds., Methods of Soil Analysis, Part 2. Chemical and Microbiological Methods, American Society of Agronomy, Madison, 1982, pp. 539-579.

[24] Food and Agriculture Organization of the United Nations/ International Soil Reference and Information Centre, "World References Base for Soil Resources,” World Soil Reports, Rome, 2006.

[25] V. B. Nico, “Soil Formation,” 2nd Edition, Kluwer Academic Publisher, Secaucus, 2002.

[26] P. A. Tamfuh, E. D. Woumfo, D. Bitom, D. Njopwouo, "Petrological, Physico-Chemical and Mechanical Characterization of the Topomorphic Vertisols from the SudanoSahelian Region of North Cameroon,” The Open Geology Journal, Vol. 5, 2011, pp. 33-55.

[27] B. P. Yerima, "Weathering and Genesis of Volcanic Ash-Influenced Vertisols and Vertisol-Like Soils of ElSalvador," Master's Thesis, Texas A\&M University, College Station, 1983.
[28] H. Ekinci, H. Özcan, Y. Yigini, V. Cavusgil, O. Yüksel and Y. Kavdir, "Profile Developments and Some Properties of Vertisols Formed on Different Physiographic Units," International Soil Congress on Natural Resource Management for Sustainable Development, Erzurum, 2004.

[29] H. Jenny, “The Soil Resource,” Springer, New York, 1980.

[30] T. Bhattacharyya, P. Chandran, S. K. Ray, C. Mandal, D. K. Pal, M. V. Venugopalan, S. L. Durge, P. Srivastava, P. N. Dubey, G. K. Kamble, R. P. Sharma, S. P. Wani, T. J. Rego, P. Pathak, V. Ramesh, M. C. Manna and K. L. Sahrawat, "Physical and Chemical Properties of Red and Black Soils of Selected Benchmark Spots for Carbon Sequestration Studies in Semi-Arid Tropics of India,” Global Theme on Agroecosystems Report, No. 35, 2007, p. 239.

[31] C. A. Stiles, "Pedogenic Relationships in a Vertisol Climosequence Defined by Geochemical Mass Balance of Whole Soil and Chemistry of Iron-Manganese Nodules,” Ph.D. Thesis, The University of Tennessee, Knoxville, 2001.

[32] M. Jamagne, "Fundamentals and Techniques of Soil Mapping," Annals of Agronomy Journal, Vol. 18, 1967, pp. 271-414.

[33] R. Kızılkaya and O. Dengiz, "Variation of Land Use and Land Cover Effects on Some Soil Physico-Chemical Characteristics and Soil Enzyme Activity," Zemdirbyste-Agriculture, Vol. 97, No. 2, 2010, pp. 15-24.

[34] K. R. Islam and R. R. Weil, "Land Use Effects on Soil Quality in a Tropical Forest Ecosystem of Bangladesh”, Agriculture, Ecosystems and Environment, Vol. 79, No. 1, 2000, pp. 9-16. doi:10.1016/S0167-8809(99)00145-0

[35] R. Dudal, "Dark Clay Soils of Tropical and Subtropical Regions,” Agriculture Development Paper, No. 83, 1965, p. 161.

[36] D. F. Yule and J. T. Ritchie, "Soil Shrinkage Relationship of Texas Vertisols Small Cores," Soil Science Society of America Journal, Vol. 44, No. 6, 1980, pp.1285-1291. doi:10.2136/sssaj1980.03615995004400060031x

[37] S. K. Shirsath, T. Bhattacharyya and D. K. Pal, "Minimum Threshold Value of Smectite for Vertic Properties," Australian Journal of Soil Research, Vol. 38, No. 1, 2000, pp. 189-201. doi:10.1071/SR99051

[38] D. McGarry, "The Structure and Grain Size Distribution of Vertisols," In: N. Ahmad and A. Mermut, Eds., Vertisols and Technologies for Their Management, Developments on Soil Science, Elsevier, Amsterdam, 1996, pp. 231-259.

[39] U. P. Pillai and D. McGarry, "Structure Repair of a Compacted Vertisol with Wet-Dry Cycles and Crops," Soil Science Society of America Journal, Vol. 63, No. 1, 1999, pp. 201210. doi:10.2136/sssaj1999.03615995006300010029x

[40] C. Culpin, “Farm Machinery,” 10th Edition, Grand Publishing Ltd., London, 1981.

[41] R. L. Hill, "Long-Term Conventional Tillage and No-Tillage Effects on Selected Soil Physical Properties,” Soil Science Society of America Journal, Vol. 54, No. 1, 1990, pp. 161166. doi:10.2136/sssaj1990.03615995005400010025x

[42] P. K. Singh, and Y. Singh, "Effect of Reduced Tillage on Soil Properties, Root Growth and Grain Yield in RiceWheat System,” Indian Journal of Agricultural Research, Vol. 30, 1996, pp.179-185. 